\title{
Eclogites from the Colorado Plateau: A Phanerozoic Record of Subduction beneath North America
}

Ruiz, J. ${ }^{1}$, McCandless, T.E. ${ }^{1}$, and Helmstaedt, H.H. ${ }^{2}$

1. Center for Mineral Resources, Department of Geosciences, University of Arizona, Tucson, Arizona, USA 85721

2. Department of Geological Sciences, Queen's University, Kingston, Ontario, KTL 3N6, Canada

Twenty-five years ago, Helmstaedt and Doig (1975) proposed that eclogite facies xenoliths in diatremes from the Colorado Plateau could represent subducted remnants of Phanerozoic oceanic lithosphere, in particular the Farallon Plate. The subduction hypothesis for generating mantle eclogite has since gained considerable favour, especially for high P-T eclogites in kimberlites (Helmstaedt and Shulze, 1988; Snyder et al., 1993; Jerde et al., 1993; Jacob et al., 1994; Pearson et al., 1995; Rudnick, 1995; Viljoen et al., 1996; McCandless and Gurney, 1997). The initial premise of Helmstaedt and Doig (1975), which was based largely on observational evidence, however, would remain untested "until the precise ages of the protoliths...are known" (Helmstaedt and Shulze, 1991).

Helmstaedt and Doig (1975) noted that Colorado Plateau eclogites had ${ }^{87} \mathrm{Sr} /{ }^{86} \mathrm{Sr}$ ratios similar to Franciscan metavolcanic rocks. Wendlandt et al., (1993) obtained Proterozoic Sm-Nd model ages for eclogites from the Colorado Plateau, but noted that a number of the xenoliths experienced metasomatism that introduced LREE, $\mathrm{SiO}_{2}$ and $\mathrm{Na}_{2} \mathrm{O}$ and disturbed the $\mathrm{Nd}$ and $\mathrm{Sr}$ isotopic compositions. $\mathrm{Rb}-\mathrm{Sr}$ isochrons yield 500-900 Ma ages, and mineral and whole-rock Sm-Nd isochrons yield $21 \mathrm{Ma}$ ages, the age of the transporting magmas (Wendlandt et al., 1993). Equivocal ages were also reported previously by Roden et al., (1990).

Based on modeling by McCandless and Gurney (1997), carbon (and sulphide) bearing eclogites are more likely to be Proterozoic or younger. We specifically selected eclogites from the Colorado Plateau that contained $\sim 1 \%$ by volume of sulphides. We also selected only xenoliths from diatreme host rocks, because these are less prone to alteration than xenoliths transported in higher temperature minette or latite host magmas (Helmstaedt and Schulze, 1991). Portions of the xenoliths free of alteration of the sulphides were selected, fragments were powdered in an alumina mill, 2 grams were loaded into Carius tubes, and a modified dissolution/distillation technique (after Freydier et al., 1997) was employed to ensure recovery of Re and Os from sulphides. Total blanks with this technique are $\sim 4 \mathrm{pg}$.

Two types of eclogites were analysed for Re-Os isotopes. The metabasic eclogites consist of zoned almandine-rich garnet, omphacite, rutile, and pyrite. Metabasic eclogites have spillitic bulk compositions, and sample MR23 exhibits relict pillow basalt textures (Helmstaedt and Shulze, 1988). In contrast, the jadeite-clinopyroxenites have jadeite-rich pyroxene $+/$ - garnet, rutile or pyrite, do not have an igneous bulk composition, and resemble jadeite pods in high pressure subduction terranes (Helmstaedt and Schulze, 1988; 1991). Re-Os model ages for the metabasic eclogites MR23, MR22, and MR21 suggest that they derived from Phanerozoic subducted oceanic lithosphere, with $\mathrm{T}_{\mathrm{ma}}$ of 402.4, 334.1, and 205.1 Ma, respectively (Table 1). An early Mesozoic age for MR21 suggests that it is very likely a fragment of the subducted and eclogitised Farallon Plate, as the oldest sea floor in the Pacific Plate (a mirror image of the Farallon Plate) is about 200 Ma. These data support the original hypothesis of Helmstaedt and Doig (1975), that the Farallon Plate is represented in the Colorado Plateau eclogite suite. Samples MR22 and MR23 sare interpreted to represent remnants of earlier Phanerozoic subduction beneath North America.

Metabasic eclogite MR51, has a Proterozoic model age of $1344 \mathrm{Ma}$, similar to the Re-Os model age obtained for a Colorado Plateau websterite from a latite igneous host (1337 Ma; Esperança et al., 
1997). The data support an earlier event that could explain magmatism in southwestern North America at $\sim 1.4 \mathrm{Ga}$ (Esperança et al., 1997).

Table 1. Re-Os data for eclogites from the Colorado Plateau.

\begin{tabular}{|c|c|c|c|c|c|}
\hline sample & Re, ppb & Os, ppb & ${ }^{187} \mathrm{Re} / 188 \mathrm{Os}$ & $187 \mathrm{Os} / 188 \mathrm{Os}$ & $\mathbf{T}_{\mathbf{m a}}$ \\
\hline \multicolumn{6}{|c|}{ metabasic eclogite } \\
\hline MR21 & 1.447 & 0.105 & $\begin{array}{r}68.4 \\
\pm 0.1 \\
\end{array}$ & $\begin{array}{r}0.3616 \\
\pm 0.0004 \\
\end{array}$ & 205 \\
\hline MR22 & 0.769 & $\begin{array}{c}0.048 \\
-\end{array}$ & $\begin{array}{r}82.7 \\
\pm 0.6 \\
\end{array}$ & $\begin{array}{r}0.682 \\
\pm 0.002 \\
\end{array}$ & 402 \\
\hline MR23 & 1.055 & 0.331 & $\begin{array}{r}15.5 \\
\pm 0.03\end{array}$ & $\begin{array}{r}0.2131 \\
\pm 0.0005\end{array}$ & 334 \\
\hline MR51 & 0.139 & 0.064 & $\begin{array}{r}10.8 \\
\pm 0.23 \\
\end{array}$ & $\begin{array}{r}0.365 \\
\pm 0.002 \\
\end{array}$ & 1344 \\
\hline \multicolumn{6}{|c|}{ jadeite-clinopyroxenite } \\
\hline MR24 & 0.181 & 0.318 & $\begin{array}{r}2.79 \\
\pm 0.04 \\
\end{array}$ & $\begin{array}{r}0.2202 \\
\pm 0.0004\end{array}$ & 2278 \\
\hline
\end{tabular}

$\mathrm{T}_{\mathrm{ma}}$ determined using $\lambda=1.666 \times 10^{-11}$ (Smoliar et al., 1996), ${ }^{187} \mathrm{Os} /{ }^{188} \mathrm{Os}=0.1287$, and ${ }^{187} \mathrm{Re} /{ }^{188} \mathrm{Os}=0.4243$ (Meisel and Walker, 1996). Reported uncertainties are $2 \sigma$.

Garnet websterite MR24, with a $\mathrm{T}_{\mathrm{ma}}$ of $2278 \mathrm{Ma}$, is older than known basement rocks in the region, and with a lack of igneous textural and chemical characteristics, could represent early subducted material that has since been isolated from subsequent igneous modification. A strikingly similar model age of $2310 \mathrm{Ma}$ was obtained for an eclogite by Esperança et al., (1997). Interestingly, the remaining few eclogites analysed by Esperança et al., (1997) are also Proterozoic (901, 759, 785, $825 \mathrm{Ma})$. We attribute this difference to our emphasis on analysing eclogites with high sulphide contents as the best candidates for subducted Phanerozoic oceanic lithosphere. However, when all the Re-Os isotope data are considered, they represent a record of subduction of oceanic lithosphere beneath North America that persisted for nearly $2 \mathrm{Ga}$.

\section{References}

Esperança, S., Carlson, R.W., Shirey, S.B., and Smith, D., 1997, Dating crust-mantle separation: Re-Os isotopic study of mafic xenoliths from central Arizona: Geology, 25, p.651-654.

Freydier, C., Ruiz, J., Chesley, J.T., McCandless, T.E. and Munizaga, F., 1997, Re-Os systematics of sulfides from felsic igneous rocks: application to base metal porphyry mineralization in Chile: Geology, 25, p.775-778.

Helmstaedt, H.H., and Doig, R., 1975, Eclogite nodules from kimberlites of the Colorado Plateau: Samples of subducted Franciscan-type oceanic lithosphere: Phys. Chem Earth, 9, p.95-111. 
subduction gypothesis, and implications for eclogite xenoliths from diamondiferous kimberlites: in Eclogites and Eclogite-Facies Rocks, edited by D. C. Smith, pp. 387-450, Elsevier, New York.

Helmstaedt, H.H. and Schulze, D.J., 1989, Southern African kimberlites and their mantle sample: implications for Archean tectonics and lithosphere evolution: in: Kimberlite and Related Rocks, Volume 2: Their Mantle/Crust Setting, Diamonds and Diamond Exploration., J.M. Ross, ed., pp. 358-368, Blackwell Scientific, Victoria, Australia.

Helmstaedt, H.H. and Schulze, D.J., 1991, Early to mid-Tertiary inverted metamorphic gradient under the Colorado Plateau: evidence from eclogite xenoliths in ultramafic microbreccias, Navajo volcanic field: J. Geophys. Res., 896, p.13225-13235.

Jacob, D., Jagoutz, E., Lowry, D. Mattey, D. and Kudrjavtseva, G., 1994, Diamondiferous eclogites from Siberia: remants of Archean ocean crust: Geochim. Cosmochim. Acta 58, p.51915207.

Jerde, E.A., Taylor, L.A., Crozaz, G., Sobolev, N.V. and Sobolev, V.N., 1993, Diamondiferous eclogites from Yakutia, Siberia: evidence for a diversity of protoliths: Contrib. Mineral. Petrol. 114, p.189-902.

McCandless, T.E. and Gurney, J.J., 1997, Diamond eclogites: comparison with carbonaceous chondrites, carbonaceous shales, and microbial carbon-enriched MORB: in: N.V. Sobolev and R.H. Mitchell (Eds.) 6th International Kimberlite Conference Volume 2, Diamonds: Characterization, Genesis and Exploration. Russian Geology and Geophysics, 38, p.394-404, Allerton Press, New York.

Pearson D. G., Snyder, G.A., Shirey, S.B., Taylor, L.A., Sobolev, N. V., 1995, Archaean Re-Os age for Siberian eclogites and constraints on Archaean tectonics: Nature, 374, 711-713.

Roden, M. F., Smith, D. and Murthy, V. R., 1990, Geochemical constraints on lithosphere composition and evolution beneath the Colorado Plateau: J. Geophys. Res., 95, p.2811-2831.

Smoliar, M.I., Walker, R.J. and Morgan, J.W., 1996, Re-Os ages of group IIA, IIIA, IVA, and IVB iron from meteorites: Science, 271, p.1099-1102.

Viljoen, K.S., Smith, C.B., and Sharp, Z.D., 1996, Stable and radiogenic isotope study of eclogite xenoliths from the Orapa kimberlite, Botswana: Chem. Geol., 131, p.235-255.

Rudnick, R.L. Eclogite xenoliths: samples of Archean ocean floor, extended abstract: 6th International Kimberlite Conference, Extended Abstracts, United Institute of Geology, Geophysics \& Mieralogy, Novosibirsk, Siberia, pp. 473-475, 1995.

Snyder, G.A., Jerde, E.A., Taylor, L.N., Halliday, A.N., Sobolev, V.S. and Sobolev, N.V., 1993, $\mathrm{Nd}$ and $\mathrm{Sr}$ siotopes from diamondiferous eclogites, Udachnaya kimberlite pipe, Yakutia, Siberia: evidence of differentiation in the early Earth?: Earth Planet. Sci. Lett. 118, p.91-100.

Wendlandt E., DePaolo, D.J. and Baldridge, W.S., 1993, Nd and Sr isotope chronostratigraphy of Colorado Plateau lithosphere: implications for magmatic and tectonic underplating of the continental crust: Earth Planet. Sci. Lett., 116, p.23-43. 